\title{
Determination of the Air Purification Efficiency when Using a Biofilter
}

\author{
Ivan Krivolapov'*, Andrej Astapov'1, Dmitrij Akishin', \\ Artemij Korotkov', Sergej Shcherbakov ${ }^{1}$ \\ 1 Michurinsk State Agrarian University, Ulitsa Internatsional'naya, 101, Michurinsk, Tambov Oblast, 393740, \\ Russia \\ * Corresponding author's e-mail: ip.krivolapov@mail.ru
}

\begin{abstract}
The work presents the results of experimental studies on the air purification efficiency after accelerated composting of a mixture of cattle manure and straw in a chamber-type biofermenter. The operation of an experimental plant that simulates this process was described. A process optimization criterion was established, its values were determined for each of the pollutants - ammonia and hydrogen sulfide. The maximum purification efficiency for ammonia was $92 \%$, achieved at $47 \%$ moisture content of the filtering material and $58 \%$ compost weight parts at $30{ }^{\circ} \mathrm{C}$. For hydrogen sulfide, the maximum purification efficiency was $95 \%$, achieved at $50 \%$ moisture content of the filtering material and $52 \%$ compost weight part at $28{ }^{\circ} \mathrm{C}$.
\end{abstract}

Keywords: biofiltration, ammonia, hydrogen sulfide, purification efficiency, filtering material.

\section{INTRODUCTION}

The global climate change is largely determined by the human impact on the environment. Despite the measures taken under the United Nations Framework Convention on Climate Change to limit the emissions of harmful substances, their concentration continues to grow. According to the European Union Environmental Commission [Klimat, ekologiya, selskoe hozyaistvo Evrazii 2014; Krivolapov et al. 2018], over $80 \%$ of ammonia polluting the atmosphere and $10 \%$ of methane destroying the ozone layer comes from manure and litter due to their untimely incorporation into the soil and storage in open accumulators. The environmentalists in Europe also believe that the unsatisfactory management of manure and litter is the main cause of the formation of nitrogen-containing acid rain. Therefore, the processing of organic agricultural waste should ensure sufficiently effective production of valuable products and minimize the possible consequences of pollution.
One of the purposes of the State Program for the Development of Agriculture and Regulation of Agricultural Products, Raw Materials and Food for 2013-2020 [Gosudarstvennaya programma razvitiya selskogo hozyaistva i regulirovaniya rynkov selskohozyaistvennoi produktsii, syrya i prodovolstviya na 2013-2020 gg. 2012] is reproduction and improvement in the efficiency of land and other resources used in agriculture, as well as production ecologization. In order to achieve these and a number of other objectives, the program is aimed at solving several tasks, including the ecologically regulated use of land, water and other renewable natural resources, as well as the improvement of soil fertility to the optimum level in each zone.

Today, the growth in livestock production and its location in small areas raise an urgent problem for the most livestock farms - waste processing and associated air pollution, the treatment of which is one of the main measures to protect the air basin. Treatment of emissions before they are released into the atmosphere is of high sanitary, environmental and economic importance. 


\section{MATERIALS AND METHODS}

The research conducted by Russian, American and European scientists shows that up to 45 different substances are contained in the air of livestock buildings, including ammonia, hydrogen sulfide, indole, phenol, skatole, organic acids, etc. It was noted that the odor from livestock farms extends over 2-10 km [Crittenden 2002; Nicolai, Lefers 2015; Richard, Schmidt 2005; Krivolapov et al. 2016]. One of the possible solutions is the use of air filtration technology based on the use of microorganisms that absorb the harmful emission components and use them for their own growth and development.

In the course of earlier studies [Richard, Schmidt 2005], it was found that the accelerated biochemical decomposition of the components of the straw-manure mixture in chamber installations leads to an increase in the temperature of the mixture to $60-65^{\circ} \mathrm{C}$. As a result, a significant amount of gases containing hydrogen sulfide and ammonia, the concentration of which varies from 15 to 22 and from 70 to $115 \mathrm{mg} / \mathrm{m}^{3}$ respectively, is emitted, which exceeds the maximum permissible levels by $2-5.5$ times. Therefore, there is a need to purify the air contaminated during the process.

Various methods, based on thermal, mechanical and chemical effects are used to purify the air from ammonia and hydrogen sulfide. These methods ensure a 95-99\% efficiency of air purification. However, these technologies are rarely used in agriculture due to their high cost, design complexity and requirements for highly qualified maintenance.

The air filtration technologies using microorganisms are becoming more popular today due to their relatively low cost, simple design and maintenance. They are based on passing gases through a porous, usually organic, carrier-filtering material: compost from animal waste, peat, heather, coconut palm, paper granules, etc. During the operation, a biological film is formed on the surface of such filtering material with microorganisms-destructors, which decompose the emission components to harmless $\mathrm{H}_{2} \mathrm{O}$ and $\mathrm{CO}_{2}$. At the same time, it is known that the organic substances contained in the filtering material are not capable of fully providing the energy to destructive microorganisms. Therefore, one of the important conditions for the effective operation of the installation is the optimization of the chemical composition of the filtering material where the microorganisms develop, as well as the selection of the optimal nutrient solution composition that is supplied to its surface. Such a solution contains the substances necessary for the normal growth and development of these microorganisms [Vinarov et al. 1986; Krivolapov 2011].

In the process of biofiltration, the components of the gaseous emission enter the structure of the biofilter according to successive stages: they are adsorbed by the surface of the pores of the filtering material, then they move in the direction of change of the pressure gradient and concentration, penetrate the liquid biological film and are utilized by the enzymes of destructive microorganisms using the incoming components for their growth and development.

The biofiltration of gases includes the processes of mass transfer, sorption and biological decomposition and, in general, can be expressed by the equation

$$
q_{\text {out }}=q_{\text {in }}-\left(q_{a d s}+q_{a b s}+q_{\text {bio }}\right)
$$

where $q_{\text {out }}$ is the total amount of substance remaining after passing through the biofiltering material, mol;

$q_{i n}$ - the amount of substance entering the biofilter, mol;

$q_{\text {ads }} q_{\text {abs }}, q_{\text {bio }}$ - the amount of substance absorbed in the process of adsorption, absorption and microbiological decomposition, respectively, mol.

The source [Crittenden et al. 2002] considers the filtration processes in a liquid film in both three and two stages. In the first case, this process includes the gas phase, phase of entering the liquid film, and filtration in a biological film.

The process takes into account:

- mass transfer of gaseous substance by adventive flow in gas and liquid;

- mass transfer at the gas-liquid and liquid-biofilm boundaries;

- internal diffusion in a biofilm;

- active growth of biomass and its decay (biological reaction in a biofilm).

When using a two-phase model, the liquid and adventive flows are eliminated, while the gas-liquid transfer processes and the liquid-biofilm are combined into one - gas-biofilm [Crittenden et al. 2002; Nicolai, Lefers 2005; Richard, Schmidt 2005].

Mass transfer between gas and liquid can be described using the theory of two films [Crittenden et al. 2002; Kafarov 1979; Zavrazhnov et al. 2014]. 
It is assumed that all the resistance during mass transfer is due to the liquid. Therefore, there is no concentration gradient in the gas flow and the mass flow at the gas-liquid interface $\left(J_{L}\right)$ can be determined using the total mass transfer coefficient $K_{L}$ and the hypothetical concentration in the liquid $C_{l s}^{*}$ determined by Henry's law [Crittenden et al. 2002]:

$$
J_{L}=K_{L}\left(C_{l s}^{*}-C_{l}\right)=K_{L}\left(\frac{C_{g}}{H}-C_{l}\right)
$$

where $H$ is the Henry's law constant.

The mass transfer coefficient can be found using the following expression:

$$
\frac{1}{K_{L}}=\frac{1}{k_{l}}+\frac{1}{k_{g} H}
$$

where $k_{g}$ and $k_{l}$ are the mass transfer coefficients on the gas and liquid sides, respectively.

Mass transfer at the liquid-biofilm boundary $\left(J_{F}\right)$ is determined by the following equation [Crittenden et al. 2002]:

$$
J_{F}=K_{f}\left[C_{l}-C_{b}(x=0)\right]
$$

where $K_{f}$ is the film transfer coefficient at the liquid-biofilm boundary and

$C_{b}(x=0)$ is the concentration of the pollutant on the biofilm surface.

Mass transfer inside a biofilm $\left(J_{B}\right)$ is determined by Fick's law:

$$
J_{B}=-D_{b} \frac{\partial C_{b}}{\partial x}
$$

where $D_{b}$ is the effective diffusion coefficient in the biofilm;

$C_{b}$ - the concentration of the pollutant in the biofilm;

$x$ - the thickness of the biofilm.

The film thickness is usually determined when taking into account mass transfer as the equivalent film thickness across the boundary laminar layer from the mass transfer coefficient found experimentally and the diffusion coefficient and can be determined as follows [Bykov 1985; Krivolapov et al. 2016]:

$$
x=\frac{0,23 \operatorname{Re}^{0,83} S c^{0,44}}{S}
$$

where $S$ is the contact area of the phases, $\mathrm{m}^{2}$, $R e$ - the Reynolds number, $(\operatorname{Re}=u D \rho / \mu)$, $S c$ - the Schmidt number.
Filtration of low soluble substances can be considered from the point of view of the film theory and the penetration theory.

In both cases, it is assumed that the mass transfer process is determined by the mass transfer of the gaseous product in the liquid, that is [Kafarov 1979; Zavrazhnov et al. 2014]:

$$
k_{L} \approx \beta_{x}
$$

where $\beta_{x}$ - mass transfer coefficient.

According to the film theory [Zavrazhnov et al. 2014], the equation for determining the mass transfer coefficient is:

$$
\beta_{x}=\frac{D}{\delta}
$$

where $\delta$ is the thickness of the liquid film, determined by the hydrodynamic conditions, decreasing with an increase in the turbulence of the medium.

The disadvantage of the film model is that it does not consider the influence of interfacial turbulence on the transfer of matter.

According to the penetration theory [Kafarov 1979], the mass transfer coefficient is determined by the equation:

$$
\beta_{x}=2 \sqrt{\frac{D_{M}}{\pi \tau_{k}}}
$$

where $\tau_{k}$ is the contact time equal to the time during which the gas dissolves in the surface element due to non-stationary diffusion. Assume that the contact time is distributed in accordance with the ratio $L e^{-L \tau k}$ then the expression above can be presented as:

$$
\beta_{x}=\sqrt{D_{M} L}
$$

where $L$ is the surface renewal rate.

The process of substance transfer from the interface to the liquid phase, in this case, is described by the convective diffusion equation:

$$
\frac{\partial C}{\partial t}=D_{L} \frac{\partial^{2} C}{\partial z^{2}}-W \frac{\partial C}{\partial y}
$$

where $y$ is the coordinate parallel to the phase interface;

$z$ - is the coordinate normal to the interface;

$W$ - is the flow rate;

$D_{L}-$ a diffusion coefficient [Zavrazhnov et al 2014]. 
For standard conditions and fixed media $(\mathrm{W}=0)$, obtain:

$$
D_{L} \frac{\partial^{2} C}{\partial z^{2}}=0
$$

This expression describes the diffusion of low soluble components in the bulk of the liquid phase based on film theory. According to the theory, the main resistance to mass transfer is concentrated in a thin layer of liquid adjacent to the interface and the process is stationary $\left(\frac{\partial C}{\partial t}=0\right)$. When a flow moves at a constant speed, equation 11 takes the following form:

$$
\frac{\partial C}{\partial t}=D_{L} \frac{\partial^{2} C}{\partial z^{2}}
$$

This formula describes the diffusion of a component in the liquid phase. According to the penetration theory, the renewal of the contact surface of the phases occurs at certain equal intervals of time. In accordance with the renewal theory, the contact time is characterized by a random value.
In order to establish the true values of the efficiency of microbiological decomposition using biofiltration technology, a technique and an experimental installation for evaluating the purification efficiency were developed [Krivolapov, Mironov 2012, Krivolapov et al. 2016] (Figure 1).

The installation consists of a thermally insulated tank 1 , in which a straw-manure mixture 2 is placed, an aluminum duct 3 is connected to an exhaust fan 4, which is operated using the control unit 5 , the duct is connected to the body of the biofilter 6 , inside which filtering material 8 is located on the metal grid 7 . Gas vent 9 is used to estimate the quantitative value of the concentration of gases at the inlet and at the outlet of the biofilter.

The installation operates as follows: the straw-manure mix 2 in a ratio of $1: 1$ by weight, of $65-70 \%$ humidity and volume of $1 \mathrm{~m}^{3}$, was brought to a temperature of $45-50{ }^{\circ} \mathrm{C}$ and loaded into a thermally insulated container 1 (height $1.6 \mathrm{~m}$ and length $-1 \mathrm{~m}$ ) located on a metal grid with $25 \mathrm{~mm}$ cells at a height of $0.3 \mathrm{~m}$ from the ground.

In the thermally insulated tank, through the use of a polymeric material, the gas emissions

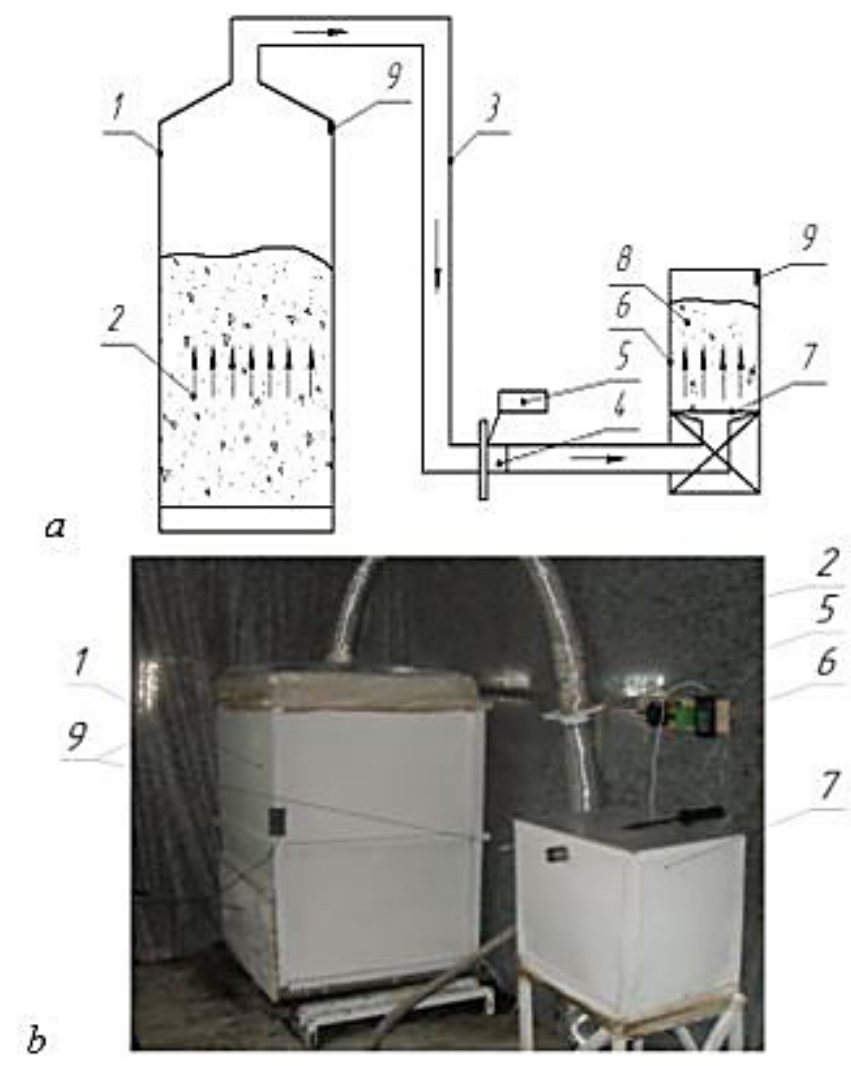

Figure 1. Scheme (a) and general view (b) of a laboratory unit for studying the biofiltration process.

1 - insulated tank; 2 - straw-manure mixture; 3 - aluminum duct; 4 - exhaust fan;

5 - fan control unit; 6 - biofilter; 7 - metal mesh; 8 - filtering layer; 9 -gas vent 
were collected, which entered the aluminum duct 3. An exhaust fan 4 was used to force the straw-manure mixture and move the gas emission to the surface of the filter layer.

The gas emission entered the body of the biofilter 6 through the use of exhaust fan, where it was evenly distributed over the surface of the filtering material 8 .

The installation was controlled by a control unit 6 , which includes a magnetic starter and a VL-78-C UHL4 time relay, the contacts of which power the magnetic starter winding connected to an exhaust fan 5. The time relay operates in $1 / 24$ mode, i.e. the fan works for 1 minute, then the time relay opens the contacts of the magnetic starter, which, in turn, turns off the fan and turns it on again after 24 minutes.

The control of the velocity of the purified air after the biofilter was carried out using a TKA-PKM thermohygro-anemometer model 60.

The efficiency of the biofilter was determined based on the analysis of the concentration of gas emissions at the outlet of the thermally insulated tank 1 and biofilter 7 , through the use of indicator tubes and the pump of the NP-3M sampler connected to the gas vent 9 located in the compostable tank and the biofilter.

In accordance with the research methodology, the mixtures in which the mass fraction of compost varied from 30 to $70 \%$, were used as the filtering materials.

The moisture content of each type of filtering material was 40,50 and $60 \%$. The temperature in the biofilter ranged from $20^{\circ}-40^{\circ} \mathrm{C}$.

The efficiency of gas treatment was chosen as a criterion for optimizing the operation of a biofilter Evaluation of the biofilter effectiveness was performed by reducing the concentration of ammonia and hydrogen sulfide.

The calculation of efficiency was carried out according to the following formulas [Krivolapov, Mironov 2012]:

$$
\begin{gathered}
\eta_{\mathrm{NH}_{3}}=\left(1-\frac{\mathrm{C}\left(\mathrm{NH}_{3}\right)_{\text {out }}}{C\left(\mathrm{NH}_{3}\right)_{\text {in }}}\right) \times 100 \% \\
\eta_{\mathrm{H}_{2} \mathrm{~S}}=\left(1-\frac{\mathrm{C}\left(\mathrm{H}_{2} \mathrm{~S}\right)_{\text {out }}}{\mathrm{C}\left(\mathrm{H}_{2} \mathrm{~S}\right)_{\text {in }}}\right) \times 100 \%
\end{gathered}
$$

where $E_{\mathrm{NH} 3}$ and $E_{\mathrm{H} 2 \mathrm{~S}}$ are the purification efficiency for ammonia and hydrogen sulfide, respectively, \%;
$\mathrm{C}\left(\mathrm{NH}_{3}\right)_{\text {in }}$ and $\mathrm{C}\left(\mathrm{H}_{2} \mathrm{~S}\right)_{\text {in }}$ - concentration of ammonia and hydrogen sulfide at the entrance to the biofilter, $\mathrm{mg} / \mathrm{m}^{3}$, $\mathrm{C}\left(\mathrm{NH}_{3}\right)_{\text {out }}$ and $\mathrm{C}\left(\mathrm{H}_{2} \mathrm{~S}\right)_{\text {out }}$-concentration of ammonia and hydrogen sulfide at the outlet of the biofilter, $\mathrm{mg} / \mathrm{m}^{3}$.

\section{RESULTS AND DISCUSSION}

On the basis of the experimental studies using a second-order non-compositional plan and the MathCAD software package, the standard deviations, Cochran's criterion values (for gas purification from ammonia, $G_{\text {calc }}=0.086$; for gas purification from hydrogen sulfide, $G_{\text {calc }}=0.052$ ), dispersion and standard deviations of the values of the regression coefficients (the average of the response and the variance in the center of the plan were as follows: when purifying the gases from ammonia $\sigma_{v E}=89.667, \sigma_{a r E}=4.333$; when purifying the gases from hydrogen sulfide $\sigma_{v E}=93.333$, $\sigma_{a r E}=8.333$ ), as well as the adequacy of the mathematical models obtained by the Fisher criterion (when purifying the gases from ammonia $F=2.79$; when purifying the gases from hydrogen sulfide $F=2.48$ ) were determined.

The following regression equations were obtained:

- the regression equation for the efficiency of gas purification from ammonia

$$
\begin{array}{r}
E_{N H 3}=89.667-3.375 x_{1}+3.87 \\
5 x_{3}-6.583 x_{1}^{2}-3.833 x_{2}^{2}-6.583 x_{3}^{2}
\end{array}
$$

- the regression equation for gas purification from hydrogen sulfide

$$
\begin{aligned}
& E_{H 2 S}=93.333-9.167 \\
& x_{1}{ }^{2}-4.667 x_{2}^{2}-7.917 x_{3}^{2}
\end{aligned}
$$

In these equations, the factors are given in the coded form. When decoding the factors, using auxiliary Table 1, the regression equations are obtained in the form:

- the decoded regression equation for the efficiency of gas purification from ammonia

$$
\begin{gathered}
E_{N H 3}=-0.066 W^{2}-0.038 t^{2}-0.016 M \\
{ }^{2}+6.245 W+2.3 t+1.84 M-143.375
\end{gathered}
$$

- the decoded regression equation for the efficiency of gas purification from hydrogen sulfide

$$
\begin{gathered}
E_{H 2 S}=-0.091 W^{2}-0.049 t^{2}-0.019 M \\
{ }^{2}+9.167 W+2.8 t+1.979 M-227.312
\end{gathered}
$$


The maximum purification efficiency for ammonia of $92 \%$ is achieved at the $47 \%$ moisture content of the filtering material and 58\% compost part by weight at the temperature of $30^{\circ} \mathrm{C}$.

For hydrogen sulfide, the maximum purification efficiency of $95 \%$ is achieved at the $50 \%$ moisture content of the filtering material and $52 \%$ compost part by weight at the temperature of $28^{\circ} \mathrm{C}$.

The 3D graphical dependencies of the gas purification efficiency from ammonia and hydrogen sulfide were built on the basis of the obtained regression models and values of factors. The average value of compost part by weight of 55\% was taken. The dependencies are presented in Figures 2 and 3.

The analysis of the response surfaces presented in these figures shows that with increasing temperature and compost weight, the purification efficiency decreases, which is caused by

Table 1. Auxiliary table for decoding coefficients in regression equations

\begin{tabular}{|c|l|}
\hline Coded indicator value & Decoded indicator value \\
\hline$x_{1}$ & $0.1 \mathrm{~W}-5$ \\
\hline $\mathrm{x}_{2}$ & $0.1 \mathrm{t}-3$ \\
\hline $\mathrm{x}_{3}$ & $0.05 \mathrm{M}-2.5$ \\
\hline $\mathrm{x}_{1} \mathrm{x}_{2}$ & $0.05 \mathrm{Wt}-0.4 \mathrm{~W}-2.5 \mathrm{t}+20$ \\
\hline $\mathrm{x}_{1} \mathrm{x}_{3}$ & $0.005 \mathrm{WM}-0.25 \mathrm{~W}-0.25 \mathrm{M}+12.5$ \\
\hline $\mathrm{x}_{2} \mathrm{x}_{3}$ & $0.025 \mathrm{Mt}-1.25 \mathrm{t}-0.2 \mathrm{M}+10$ \\
\hline $\mathrm{x}_{1}{ }^{2}$ & $0.01 \mathrm{~W}^{2}-\mathrm{W}+25$ \\
\hline $\mathrm{x}_{2}{ }^{2}$ & $0.01 \mathrm{t}^{2}-0.6 \mathrm{t}+9$ \\
\hline $\mathrm{x}_{3}{ }^{2}$ & $0.0025 \mathrm{M}^{2}-0.25 \mathrm{M}+6.25$ \\
\hline & \\
\hline
\end{tabular}

the compaction of the filtering material with increasing mass of compost and unfavorable conditions for the development of microorganisms in increasing temperature.

In order to obtain the range of optimal values, a combined contour plot of two regression models of purification efficiency was constructed, see Figure 4.

\section{CONCLUSION}

During the accelerated processing of animal waste, a significant amount of ammonia and hydrogen sulfide is released. The concentration of emissions exceeds the established maximum permissible values. The filtration technology based on microbiological decomposition allows reducing the concentration of these gaseous substances. The main factors determining the effectiveness of the biofiltration process, in this case, are the compost part of the weight, the moisture content of the filtering material and its temperature.

On the basis of the developed experimental modeling method pertaining to the accelerated composting using the technology of microbiological purification of polluted air, it was established that while maintaining the filtering material with a $55 \%$ compost part by weight, moisture content of $47-52 \%$ and temperature of $26-33^{\circ} \mathrm{C}$, the ammonia and hydrogen sulfide purification efficiency will be 91 and $94 \%$, respectively. This will ensure a decrease in the concentration of ammonia and hydrogen sulfide in the exhaust air below the set limit values.

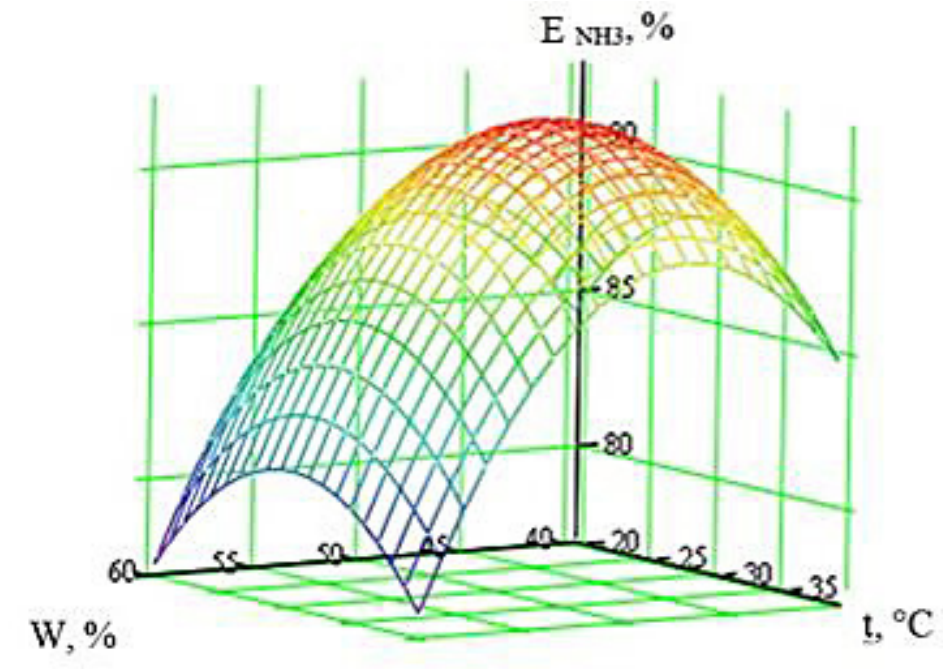

Figure 2. The response surface of the efficiency of gas purification from ammonia using filtering material with compost part by weight of $55 \%$ 


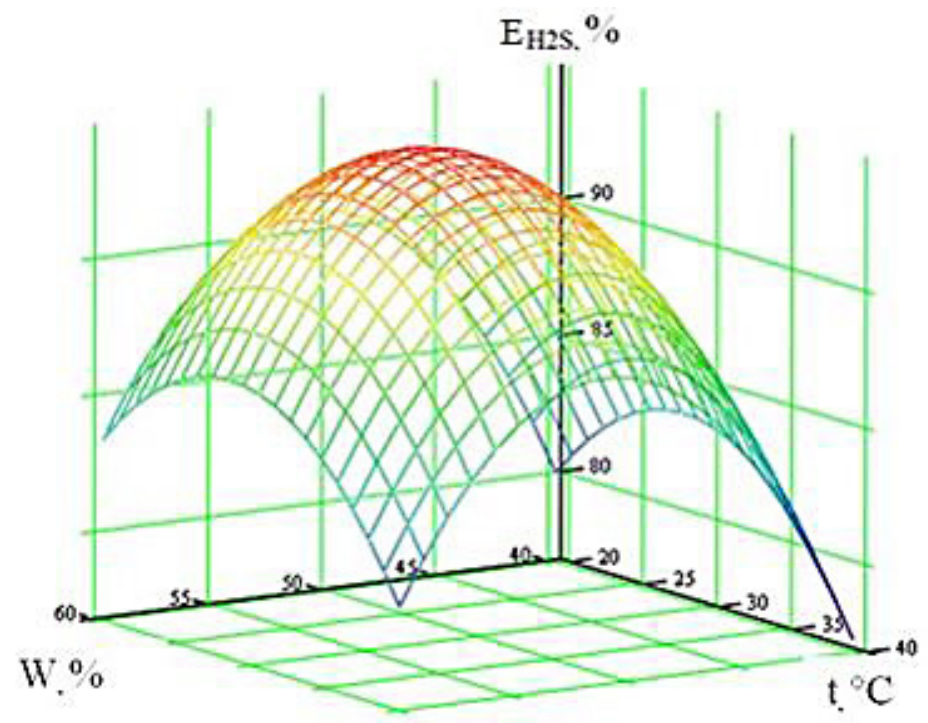

Figure 3. The response surface of the efficiency of gas purification from hydrogen sulfide using filtering material with a compost part by weight of $55 \%$

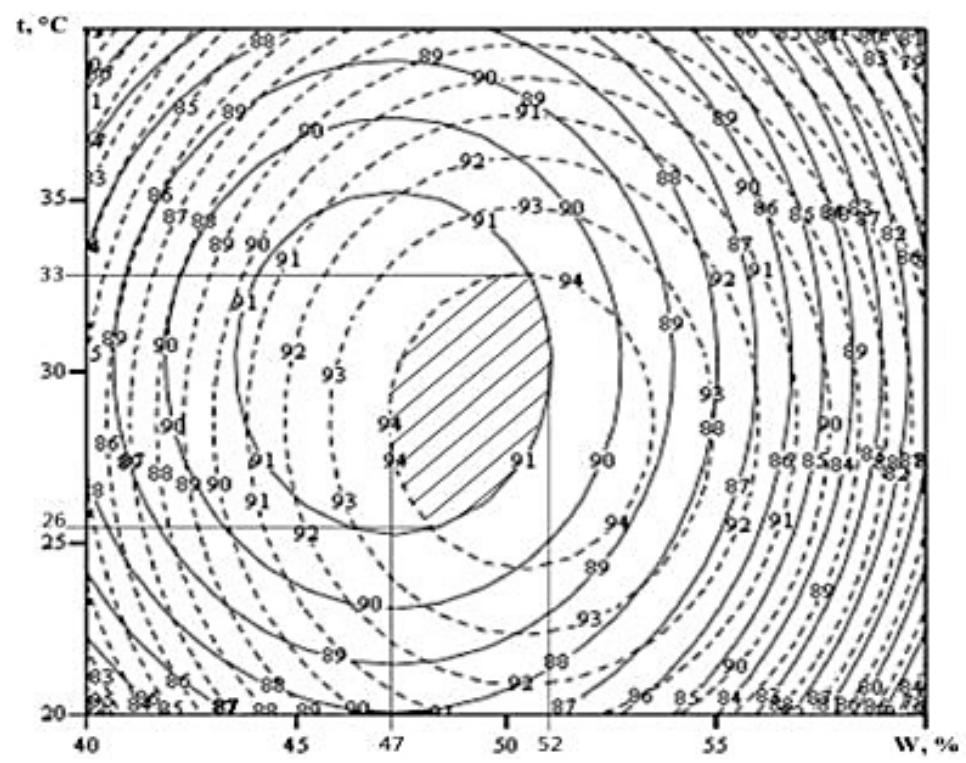

Figure 4. Combined two-dimensional sections of the response surfaces of the efficiency of gas purification from ammonia (---) and hydrogen sulfide (- - -)

\section{REFERENCES}

1. Klimat, ekologiya, selskoe hozyaistvo Evrazii [Climate, ecology, agriculture of Eurasia] (2014): Proceedings of the III International Scientific and Practical Conference dedicated to the 80th anniversary of the IGSA (27-29 May 2014). Part I. Irkutsk: Izd-vo IrGSKHA, pp. 258.

2. Krivolapov I.P., Manaenkov K.A., Shcherbakov S.Yu. Koldin M.S. 2018. Opredelenie harakteristik filtruyushchego materiala biologicheskih filtrov pri pererabotke othodov zhivotnovodstva. Agroprodovolstvennaya politika Rossii [Characterization of the filtering material of biofilters in the processing of animal waste. Agricultural and Food Policy of Russia]. Tyumen: Izd-vo OOO «Uralskii nauchnoissledovatelskii institut ekonomicheskoi i prodovolstvennoi bezopasnosti», 5, 52-56.

3. Gosudarstvennaya programma razvitiya selskogo hozyaistva i regulirovaniya rynkov selskohozyaistvennoi produktsii, syrya i prodovolstviya na 2013-2020 gg. utverzhdena postanovleniem Pravitelstva Rossiiskoi Federatsii ot 14 iyulya $2012 \mathrm{~g}$. N 717 [The state program for the development of agriculture and regulation of the markets for agricultural products, raw materials and food for 
2013-2020. approved by the Decree of the Government of the Russian Federation dated July 14, 2012 N 717]. Available: http://www.gosprog.ru/ gp-razvitiya-selskogo-hozyaystva/

4. Crittenden John C., Mihelcic James R., Michigan Hebi L. 2002. Manual biofilter design software. Technological University 1400 Townsend Drive Houghton, MI 49931, pp.105-109.

5. Nicolai R., Lefers R. 2005. Biofilters. Used to reduce emissions from livestock housing - a literature review. South Dakota State University, p. 8

6. Richard N., Schmidt D. 2005. Biofilters. South Dakota State University college of agriculture \& Biological sciences cooperative extension service, pp. 38-43.

7. Krivolapov, I.P., Shcherbakov S.Yu., Koldin, M.S. 2016. The results of the research on the efficiency of air purification from ammonia and hydrogen sulfide with peat-humus filtering material. Ecology, Environment and Conservation, 22, Suppl. Issue, 47-50.

8. Krivolapov I.P., Mironov V.V. 2012. Issledovaniya sostava gazovyh vybrosov pri kompostirovanii. In: Voprosy sovremennoi nauki i praktiki: Universitet im. V.I. Vernadskogo [Studies of the composition of gas emissions during composting. In: Questions of modern science and practice: Vernadsky University]. Tambov: Izd-vo TGTU, Vol. 1, 336-341.

9. Vinarov A.Yu., Sadyrov O.A., Lobanov F.I. 1986. Ochistka i dezodoratsiya promyshlennyh gazov s pomoshchyu mikroorganizmov. In: Itogi nauki i tekhniki. Seriya Biotekhnologiya [Cleaning and deodorization of industrial gases with the help of microorganisms. In: Results of science and technology. Biotechnology series]. Moscow: izd-vo VINITI AN SSSR, Vol. 27.

10. Krivolapov I.P. 2011. Metodika eksperimentalnogo issledovaniya biologicheskoi filtratsii gazovyh vybrosov [Methods of experimental study of biofiltration of gas emissions]. Vestnik Michurinskogo gosudarstvennogo agrarnogo universiteta. Part 2, pp. 45-49.

11. Kafarov V.V. 1979. Osnovy massoperedachi [Basics of mass transfer]. Edition 3, updated. Moscow: Vysshaya shkola.

12. Zavrazhnov A.I., Braliev M.K., Mironov V.V. 2014. Sovremennye tekhnologii i tekhnicheskie sredstva udaleniya hraneniya navoza i proizvodstva vysokokachestvennyh organicheskih udobrenii: Uchebnoe posobie [Modern technologies and technical means of manure storage removal and production of high-quality organic fertilizers: Tutorial]. Uralsk, Zapadno - Kazahstanskii agrarno - tekhnicheskii universitet imeni Zhangir Khana.

13. Bykov V.A. 1985. Raschet protsessov mikrobiologicheskih proizvodstv [Calculation of the processes of microbiological production]. Kazan: Tekhnika.

14. Krivolapov I.P. Shcherbakov S.Yu., Kudenko V.B., Aksenovskii A.V., Milovanov O.V. 2016. Opisanie osnovnyh modelei filtratsii gazov v zhidkostnoi plenke biologicheskogo filtra [Description of the main models of gas filtration in a liquid film of a biofilter]. Collection of scientific papers on the 85th anniversary of the Michurinsky State Agrarian University: in IV volumes, volume II: Technical sciences., ed. by V.A. Babushkin. Michurinsk: Izd-vo Michurinskogo GAU, pp. 27-31.

15. Krivolapov I.P., Shcherbakov S.Yu., Koldin M.S. 2016. Issledovaniya effektivnosti ochistki vozduha $\mathrm{v}$ zhivotnovodcheskih kompleksah ot ammiaka i serovodoroda [Research on the efficiency of air purification in livestock farms from ammonia and hydrogen sulfide]. Tekhnologii pishchevoi i pererabatyvayushchei promyshlennosti APK - Produkty zdorovogo pitaniya, 3 (11), 9-18. 